\title{
On First Looking into Lumley's Euripides
}

PATRICIA DEMERS

Summary: This essay explores the text of Lady Jane Lumley's Tudor translation of Iphigeneia at Aulis in an attempt to see the mind of an erudite, privileged young woman at work. By braiding domestic and political contexts in Lumley's adroitly oblique allusions to her time, it attends to her interest in the moral issues of government and authority. The translation subtly subverts commonplaces about a woman's negligible worth.

$\mathrm{B}^{\text {etween }} 1550$ and 1553 , Lady Jane Lumley, a young bride, translated B Iphigeneia at Aulis, thus producing the first English translation of a Greek drama. The manuscript volume (British Library MS Royal 15. A. IX Lumley), from which this single text has been printed twice (at the beginning and end of this century), also contains four orations of Isocrates, ${ }^{1}$ which Lady Lumley translated from Greek to Latin and dedicated to her father, Henry Fitzalan, fourteenth Earl of Arundel. ${ }^{2}$ Harold Child, the Malone Society editor, opting for the 1550 date, labels these translations "exercises of childhood," ${ }^{3}$ since he assumes that Lady Lumley was a thirteen- or fourteen-year-old girl at the time. Diane Purkiss, the recent editor, argues for 1553, largely on the basis of Arundel's confiscation of Cranmer's library, which contained two copies of Euripides' tragedy, in that year. ${ }^{4}$ Although it cannot be settled with absolute surety, the matter of the date is not insignificant. Purkiss contends that the dating of this work actually casts the play, about a father's sacrifice of a daughter to appease a goddess, move ships and win a war, and its reflections on Arundel in different lights. If it was composed in 1550, "it may be a graceful allusion to her father's efforts to serve 
the state at his own risk"; if in 1553, around the time of the debacle but before the execution the following February of Lady Jane Grey, the play transforms "the sharp fears and uncertainties of mid-Tudor politics into an elevated moral platform." Certainly, for any consideration of the turn of fortune's wheel and the attempt to use daughters and young women to advance political power - major motifs in Euripides' drama of virginal sacrifice - the three-year period of possible composition was a virtual cavalcade: the disgrace and trial for felony of Protector Somerset, whose meteoric rise was assisted by his sister's marriage to Henry VIII; Somerset's marriage of his eldest daughter to the son of his arch-rival, the Duke of Northumberland; the execution of Somerset; the death of Somerset's nephew, Edward VI; Northumberland's foiled stratagems for the coronation of his daughter-in-law, Lady Jane Grey; and the accession of Mary Tudor, the first daughter of Henry VIII. I propose to braid domestic and political contexts, already inextricably intertwined in this period, as ways of illuminating the specific and what Purkiss has termed "inescapable ... textuality of the past" in Lady Lumley's Euripides.

Lady Lumley is part of that changed "human scene" in which "women love books."7 The emphasis here is on especially young women. Lumley's youthful undertaking associates her with the "younge virgins so nouzled and trained in the studie of letters, that thei willyngly set all other vain pastimes at naught for learnynges sake," whom Nicholas Udall, Master of Eton, reported as "embrac[ing] vertuous exercises, readyng and writyng, and with most ernest studie, both erlye and late, to applye themselues to the acquiryng of knowledge, as well in all other liberall artes and disciplines," and "as familiarlye to reade or reason thereof in Greke, Latine, Frenche or Italian, as in Englishe."8 Along with her younger sister, Mary, Duchess of Norfolk, whose New Year's manuscript gifts offered to her father consisted of classical sayings translated from English and Greek to Latin, Lady Lumley joins the company of such bookish, multilingual, humanist-educated adolescents as Margaret Roper, nineteen-year-old anonymous translator of Erasmus's Treatise on the Pater Noster; Princess Elizabeth, twelve-year-old translator of Marguerite de Navarre's Le Miroir de l'âme pécheresse, with extant juvenilia including a French translation of Erasmus's Dialogus Fidei and a rendering of Queen Katherine Parr's Prayers into French, Latin and Italian; 9 Ladies Anne, Margaret and Jane Seymour, teenaged authors of Latin distichs in honour of Marguerite de Navarre (the Hecatodistichon); and, later, the accomplished daughters - Mildred, Anne, Elizabeth and Katherine - of Sir Anthony Cooke. 
What would attract Lady Jane Lumley to Iphigeneia at Aulis? Some practical answers first. It was one of two Greek tragedies that Erasmus had translated into Latin. Her husband, Lord John Lumley, having matriculated at Cambridge in 1549, himself finished a manuscript translation of Erasmus's Institution of a Christian Prince, also dedicated to Arundel in 1550. Elaine Beilin proposes that, in response to Lord Lumley's encouragement and the "implicitly Christian diction" of Erasmus's text, Lady Jane "produced ... a female version of the selfless prince," transforming Iphigeneia into "a crypto-Christian." 10 The co-editors of a new edition of the first original closet drama composed by a woman and published in English, Lady Elizabeth Cary's The Tragedy of Mariam, not only speculate "whether a later woman writer such as Cary, who shared Lumley's class status as well as her religion, might have seen a copy of her play" but also underscore the claim that "Lumley's Iphigeneia partly succeeds in rhetorically transforming herself from a political victim to a Christlike martyr." 11 Lumley is following her Greek and Latin texts in presenting the sacrifice of Iphigeneia and the appearance of the slaughtered white hart. No doubt she did see Iphigeneia as a Christ figure. Yet although Lord John and Lady Jane were both Catholics and the Arundel association with Catholicism was well known, the textual evidence I will explore in this essay does not fully support the claim that Lumley's Iphigeneia pays particular "tribute to a woman's Christian spirit, courage and eventual sanctification." 12

The extent of Lady Lumley's knowledge of the Greek language in Englishing a play that Erasmus labelled "e graeco sermone ... traducta"13 and her reliance or over-reliance on Erasmus's Latin are concerns of the few extensive examinations of her work. Over half a century ago, in rebutting David Greene's claim that Lady Lumley "had a knowledge of her original and a feeling for its verse extraordinary and rare for one of her years and her period," 14 Frank Crane excoriated the translation as "a childish performance, derived directly and carelessly from the Latin, when the text is followed at all." 15 Lady Lumley can do nothing right for Crane, who insists she shows "no knowledge of Greek, and none of poetry in any language."16 I believe that Lumley's The Tragedie of Euripides called Iphigeneia translated out of Greake into Englisshe deserves closer and more temperate scrutiny.

The second set of answers involves a more complex, speculative mix of background, life experiences and the degree of fit or imbalance between them and the layered frenzy of Euripides' tragedy. Instead of focusing on Lady Lumley's mistakes (which include some howlers), and with an awareness of the dangers of arguing from biography, I prefer to see the mind of an 
erudite and privileged young woman at work. Lady Lumley grew up with ready access to one of the finest libraries in Tudor England. Arundel was as concerned for the education of his son, Henry, whom he sent to Cambridge, as for the attainments of his two daughters and stepson, John Radcliffe, who were educated at home. Henry, Jane and Mary Fitzalan and John Radcliffe all left manuscripts of their work in the Arundel library. ${ }^{17}$ To the "influence of the daughters" Sears Jayne and Francis Johnson trace "not only the numerous volumes of exercises and translations in their own hands, but also the relative richness of the library in the Latin and Greek classics and in music." 18 As they observe, "what Arundel would never have acquired for himself he bought in profusion for his children." 19 While Purkiss emphasizes, appropriately enough, the commodity value of Lady Lumley"s education as a "sign" of Arundel's "wealth, prestige, power and fashionableness" and as a realization of the view that "to have a daughter able to read Greek was figuratively to stand near the throne," 20 I wish to recast this education from the point of view of its recipient. ${ }^{21}$ Although we have no knowledge of specific tutors, such a formation in "heuristic imitation," in "the deep assimilation and transformation of classical texts," 22 left their mark on this pupil, especially in her choice of authors and texts - Iphigeneia being "the most translated Greek tragedy in Europe in the sixteenth century" 23 and Isocrates being noted for his "exemplary prose style and moral judgements." 24

With the accession of Mary, the library of her Lord High Steward was enriched by Arundel's appropriation of Archbishop Cranmer's unparalleled collection of mainly theological works. Following the deaths of his son, the Duchess of Norfolk and his second wife, Arundel invited his surviving daughter and his son-in-law to live with him at Nonsuch Palace in Surrey; the impressive Lumley collection of books and paintings, therefore, was moved from Lumley Castle near Durham and added to the library at Nonsuch, which Lord Lumley, an "enthusiastic antiquarian," 25 who served as Lord High Steward of the University of Oxford for half a century, continued to augment. Because Lumley bequeathed the library to Prince Henry in 1609 , its twenty-six hundred volumes "became part of the Royal Library, given to the British $\mathrm{Mu}$ seum in 1757 by George II."26

What can we say of Lady Lumley's achievement itself? Pearl Hogrefe conveys the tepid temperature of existing commentary by noting coolly that Arundel's daughters "used their education in quiet ways that perhaps seemed important to them." 27 Yet it is difficult to think of a project less inherently quiet and more fraught than Euripides' Iphigeneia. Preoccupied with the intermingled roncepts and occurrences of marriage and death, love and 
sacrifice, the tragedy charts the human and political consequences of Helen's extramarital affair with Paris; the agitation of her cast-off husband, Menelaus, implicates Menelaus's brother, Agamemnon, in fulfilling a fateful prophecy involving a feigned marriage and a real sacrifice: "The characters seem to know that they are caught in an inconsistent story and try to find a way out of it." 28 Accusations of deceit reverberate in the verbal jousts between the brothers, as Menelaus charges Agamemnon, who himself had raped Clytemnestra and slain her husband and suckling infant, with weak leadership, while Agamemnon counters by reminding Menelaus of his wife's public infidelity. A wife's feeling of betrayal by her husband Clytemnestra's anger at Agamemnon for consenting to the sacrifice of their daughter to appease the goddess and allow for the passage of Greek ships out of the harbour of Aulis - is matched by a husband's grief: Menelaus's anguish over the murder and rapine resulting from his wife's dalliance. An ironic contrast separates the intended bride and groom, whose nuptial ceremony is never celebrated: Achilles, the man of action, proves unsuccessful in swaying the crowd to refuse the sacrifice of innocent blood, while the virginal daughter, Iphigeneia, having resisted death, eventually offers herself, "yield[s]" her "neck" (1560), for the sake of Greek victory. Spectators or readers are left to untangle the knot of voluntary sacrifice as either suicide or a fine death. Nicole Loraux emphasizes Euripides' deliberate distortion of the significance of the sacrifice: "under the pretense that the rule of acquiescence is being respected, consent is turned into free choice, and a death to which the victim submits becomes a willing death, not to say a noble one."29

It is important to remember how daring and daunting an undertaking the solo translation of a Greek tragedy actually was "at a time when there were no commentaries, when Greek grammars and dictionaries were few and crude. ${ }^{" 30}$ As well-read an adolescent as Lady Lumley would not have missed the significance of the filial sacrifice, recalling the unhappy fate of Jephthah's daughter (Judges 11:32-40) more vividly than the last-minute substitution that saves Isaac (Genesis 22). But the intricately wound coils of sexual tension and the complex genealogies unfolded in the play must have presented real difficulties for the young, relatively sheltered translator.

Lady Lumley's prose Iphigeneia is a simplified, abbreviated, domesticated version of Euripides' verse tragedy. In many instances the reader can see how Lady Lumley is clarifying the story line, getting the family connections straight for her own benefit. She translates Erasmüs's Argumentum, absent in the Greek, correctly and fully, adding only the gloss, when Iphigeneia's arrival is reported, that "Oreste infante" is "Orestes hir brother" 
(44-45; 27-28). In exchanges with Agamemnon, Lumley's Old Man identifies Tindarus ("Tyndareus" in Euripides), as he does not in either Euripides $(46-47)^{31}$ or Erasmus $(1155 \mathrm{E})$, as "thy wiues father" $(60-61 ; 41)$. Yet later, in rendering Agamemnon's account of Tindarus's scheme with Helen's suitors to ensure their allegiance and also to give Helen free choice, Lumley does not refer

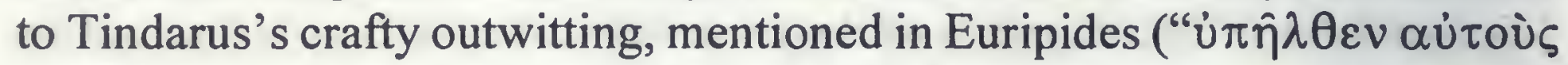

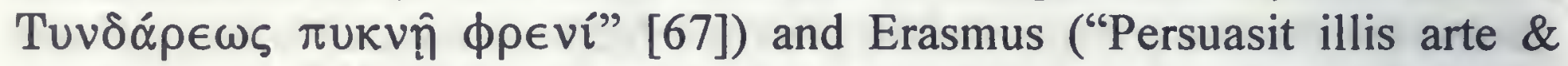
ingenio senex" [1156 B]). Her abridged translation emphasizes the narrative line, highlighting details that advance the action and deleting what must have seemed to the adolescent translator intensifying or decorative extras. The introduction of Paris as "a goodlie yonge man, and of noble parentage" (93-94; 61) neglects the particulars of his flower-starred vestment gleaming with gold bar-

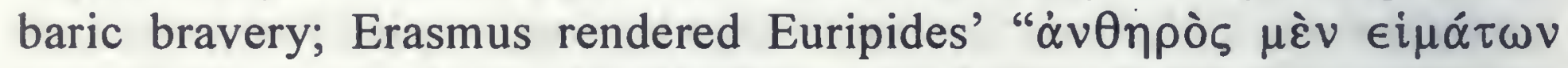

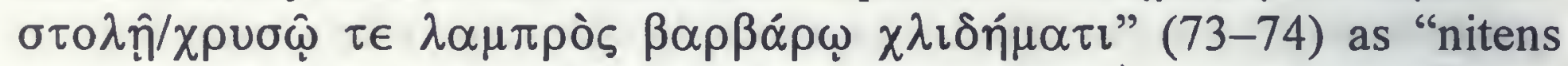
amictu floride/Auroque fulgens, barbarum videlicet/Luxum" (1156 B).

Lumley appears to favour some characters over others. Her Achilles is passionate, intense and soldierly. While Lumley stints on some of the prophetic and heraldic elements of Paris's appearance, she exaggerates Achilles' reported claim to Iphigeneia as his bride. Without precedent in either Euripides or Erasmus, Lumley's Agamemnon asserts that Achilles "was so desirous of her" (146-47; 93). Lumley includes no mention of Agamemnon's ex-

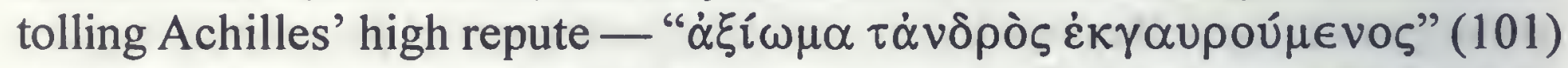
or "dignitatem exaggerans" (1156 D) - nor any self-incrimination with re-

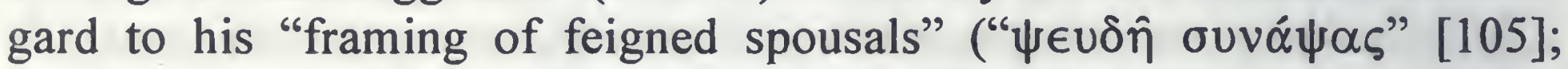
"puellae obtexo falsas nuptias" [1156 E]). There is a genuine abruptness about her Agamemnon and very little celebration of service for the public or national good. Rather, his own unease, the grim commission he is resolved to carry out and his emerging remorse make him a figure of contradictions. Lady Lumley probably found the complicity of this father in his daughter's death painful yet, in the circles she inhabited, not impossible to fathom. She does not, and could not, shy away from the fact that Grecian victory is purchased and secured with Iphigeneia's life. Her chief way of dealing with the architect of this filial sacrifice is to present Agamemnon as a king of blunt commands, conveying his first change of heart matter-of-factly but evasively:

Tell hir that she shall not nede at this time to sende my daughter hether: for her mariage shall be differred unto a nother time. (163-66; 104-6) 
However, the directive lacks the evocativeness of the instruction not to send Iphigeneia "unto the waveless shore/Of Aulis, where the bend/Of that sea-pinion of Euoboea lies/Gulf-shapen" (119-22) — poetic language, evoking the need to sacrifice to Artemis, that is present in both Greek and Latin texts.

Lumley's prose, more paraphrase than translation, is approximately three-quarters the length of the text of Euripides. ${ }^{32}$ This is paraphrase with a difference. In addressing the reader of Erasmus's Biblical paraphrases, translated into English, Udall had defined "paraphrase" as explanatory, instructive enlargement:

For a paraphrase is a plain settyng forth of a texte or sentēce more at large, with such circumstaunce of mo or other wordes, as maie make the sentēce open, clere, plain, \& familiar which otherwise should perchaunce seme bare, unfruitefull, hard, straunge, rough, obscure, and derke to be understanded of any that wer either unlearned or meanely entreed. ${ }^{33}$

Udall's emphasis on copiousness fits both the Erasmian undertaking and his own paratactic style, but it does not match Lumley's project: a paraphrase that reduces the length of the original and a manuscript, unpublished if not uncirculated for almost four centuries, whose raison d'être was the pleasure and intellectual challenge of the translator herself. The most prominent excisions are the choruses, usually preceding entrances of major characters. Therefore, Lumley's reader does not witness the strophes, antistrophes and epodes of the young married women of Chalcis reviewing the encampment at Aulis (Euripides, 163-302), assessing the frenzy and spell of Eros (542-97), prophesying the destruction of Troy (751-800) and describing the wreathing of the head of the bride (1036-98). Some of the most poignant speeches which Lumley omits are puzzling exclusions, since they involve softening or explanatory details. For instance, she does not translate Iphigeneia's tear-filled plea to Agamemnon (Euripides, 1211-52; Erasmus, 1177 E-1178 D), in which she reminds her father of such touching domestic scenes as playing on his knee and twining her fingers in his beard. Absent as well is Agamemnon's justification, his reason for having to sacrifice her to prevent the slaying of all his daughters (Euripides, 1267; Erasmus, $1178 \mathrm{~F}$ ).

This young translator does make some outright mistakes. She misconstrues the Old Man's reply to Agamemnon's change of heart not to send Iphigeneia to Aulis. Lumley's Old Man wonders, "Will not Achilles thinke you be angerie, for that under the color of him you haue determined the 
32 / Renaissance and Reformation / Renaissance et Réforme

deathe of your doughter?" (167-70; 107-8), when, in fact, it is Achilles' anger that is the real concern. For fifteen lines (405-20; 264-76) of abrupt heated exchange between Agamemnon and Menelaus, following Agamemnon's berating and goading of Menelaus and preceding the Messenger's announcement of Iphigeneia's arrival, Lumley mixes up the names of the two speakers, giving Menelaus's lines to Agamemnon and Agamemnon's to Menelaus. Neither brother is a pillar of strength, but Lumley's inversions make Agamemnon sound friendless and plaintive, with Menelaus dispensing advice about loving and not hurting one's friends and avoiding being "bewitched of some god" $(417 ; 274)$. Although Lumley's Clytemnestra adroitly

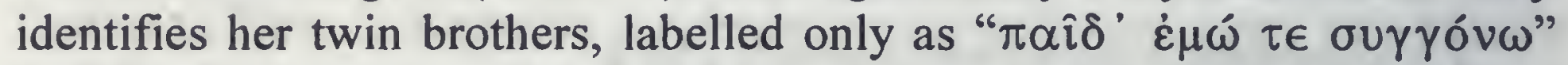
(1153) and "germanus meus" (1176 C), as "my brother Castor and Pollux" (967-68; 658-59), she sadly misrepresents her own progeny: "I happened to haue thre sones at one birthe, and afterwarde one daughter" (974-75; 662-63). As Lumley's text itself had already referred to Clytemnestra's "other daughters" (700; 470), the Greek specifies three daughters and one son, and so does the Latin: "Porro puellis editis nixu tribus,/Hunc insuper peperi tibi puellulum [sic]" (1176 E). Yet "it would not be difficult"34 to read three sons at one birth, since this could be a construal of "puellis tribus."

But Lumley also crafts several trenchant, illuminating interpretations. On an opening philosophical note, her Agamemnon observes that the "renowne" of ruling in glory and honour "is uerye brickle" $(32 ; 24)$, which to

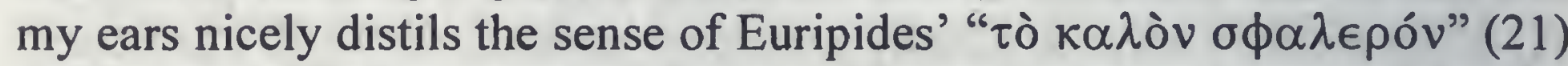
and Erasmus's "lubrica res est" $(1155 \mathrm{C})$. An obsolete word meaning "brittle, fragile, frail or weak," "brickle" supplies a pithy comment on the topsy-turvydom of mid-Tudor politics. It is an adjective and a concept Lumley may have known from reading the Bible (Wisdom 15:13; Psalms 89:9), a text well represented in her father's library. ${ }^{35}$ Although the $O E D$ cites the Authorized Version and Douay Bible, respectively, both over half a century later than the Iphigeneia project, it is not inconceivable that Lumley associated the word with a biblical context. Despite Sir Thomas More's condemnation of Wycliffe as the "great arch-heretic" whose "malicious purpose .. . corrupted the holy text," 36 Lumley may have been familiar with the passage from Wisdom in an earlier version of the Wycliffite Bible, which compares "vnwise men" to "britel vesselis," or, more likely, in the Vulgate, with its description of those "qui ex terrae materia fragilis vasa et sculptilia fingit." 37 With regard to Psalms 89:9, the Douay Bible (1609) termed man's life "as brickle as a spider's web," a rendering of this image of transience in the Vulgate: "omnes enim dies nostri transierunt." When Agamemnon is 
sparring with Menelaus, he remarks to his brother, "Indeed you file your wordes well" $(289 ; 193)$, an observation whose verb captures with intuitive

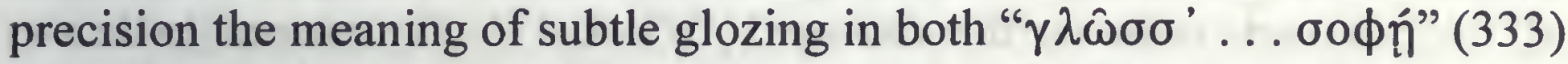
and "dicta phaleras" (1160 E). Although Lumley habitually collapses and abridges, on at least one occasion she extends and amplifies Greek and Latin texts. As Agamemnon is cataloguing his griefs, in anticipation of Iphigeneia's question, "O father will you kill me?" (468-69; 305), he concludes his speech in Lumley's version by remarking "On this parte pitie and shame, on the other side honor and glorie dothe moche moue me" (477-79; $310-11)$. An insightful extraction of the quandary facing a father who is also a king and an embattled military leader, this summation does not appear in either original.

However, when it comes to representing the sexual betrayals that have necessitated a virginal daughter's sacrifice, Lumley is much less explicit. Her Agamemnon taunts his brother, "Dothe my preferment troble you? or els dothe the desier of your bewtifull wife uexe you?" (390-92; 254-56). These suggested reactive responses differ considerably from the active yearning and righteous rebuke of Menelaus as a husband in Euripides:

\section{Dost yearn to win a virtuous wife?}

This I cannot find thee: her thou gainedst, vilely ruledst thou.

What? - must I, who have not erred, for thy transgression suffer now? (382-84)

Moreover, Lumley omits any mention of Menelaus's desire, despite the warnings of reason and honour, to clasp a lovely woman in his arms, longings Erasmus represented: "at venustam conjugem/Misso honesto, aequo, bonoque vis tenere amplexibus" (1161 E). Concupiscence is not an easy subject for Lumley. Her Clytemnestra goes as far as to label Helen "a naughtie woman" $(983 ; 668)$ and one "who hathe neuer shewed her selfe faithefull to hir husbande" (1021-22; 691-92); Euripides and Erasmus

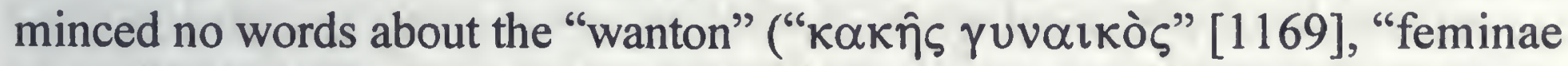
malae" [1176 E]) whose harlotry (" $\dot{\eta} \delta$ " $\dot{\xi} \xi \alpha \mu \alpha \rho \tau o v o$ " " [1204]) in breaking the sacred vows of the marriage contract ("at contra soror/Quae casta pacti jura deseruit thori" [1177 D]) made this sister such a contrast to the loyal Clytemnestra, who must forfeit her daughter.

The counterpoint to this sexual obliqueness is the domestic idiom Lumley adopts, often intensifying the poignancy of the sacrifice. In resisting Agamemnon's command that she return to Greece "to be amongste [her] other daughters" (700-1; 469-70), Lumley's Clytemnestra ironically em- 
phasizes protocol and declares herself ready. Her argument that "the mother ought to be at the mariage of the daughter" (697-98; 468-69) and "muste see all thinges made redie for the mariage" (703-4; 472-73) repeatedly throws back to the king the sham of his daughter's marriage. Lumley does not use the same contrast between "without" and "within" as Euripides' Clytemnestra, who tells her husband,

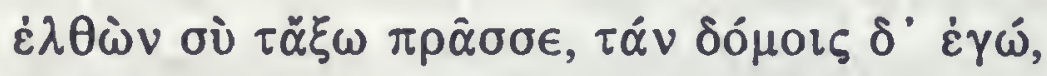

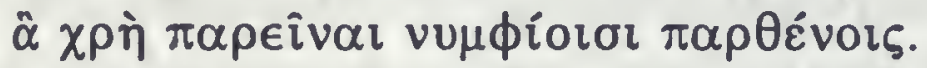

Go, order things without: within doors I

Will order what is fitting for a bride. (740-41),

or as Erasmus's queen, who contrasts outdoors business with domestic concerns: "Quin tu foris quae sunt agas negotia/Curas ego tractavero domesticas" (1168 B). But the assertiveness of Lumley's Clytemnestra, who declares, "I will not goo home yet" $(702 ; 471)$, shows that she is much more aware than jittery as a mother-of-the-"bride." Agamemnon echoes Clytemnestra's idea of readiness in his announcement, "I have prepared all thinge redie for the sacrafice" (913-14; 618-19); this statement translates Erasmus's words about the fittingly prepared means of expiation, "parata rite piamina" (1175 D). Even though it excludes the details mentioned in Euripides and Erasmus about "lustral waters," "cleansing flame" and "spirtings of dark blood," the resonating significance of being "redie" and the shift from a marriage ceremony to human sacrifice underscore with moving simplicity the inevitable outcome of these ritual preparations. To be honest, too, there are times when Lumley merely resorts to her code word "troble" to convey the boldness of the Greek or Latin. In my estimation, her rendering of the Chorus's emphatic position about the might and power of

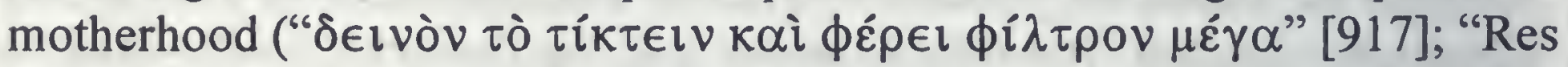
efficax peperisse, vimque maximam" [1171 E]) is pallid and prosaic: "Truly it is a uerie troblesome thinge to have childre" $(831-32 ; 563)$.

When the domestic idiom slips into this sort of encodedness, Lumley's reliance on generalizing, mollifying descriptors has the effect of reducing the passion of the play. Agamemnon's exposition, "I am in soche troble that I knowe not what to do" (553-54; 361-62), scarcely plumbs the depths of Eu-

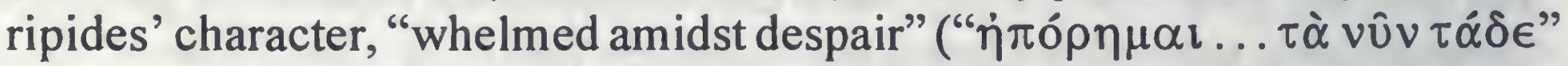
[537]); her Agamemnon is slightly more faithful to Erasmus's king: "miser," "infelix," "perplexus" (1164 B). When Lumley's Achilles expresses, through litotes, what should be a stirring to action, noting that Iphigeneia's death would be "no small dishonor to [him]" $(845 ; 572)$ and "no litell 
reproche" $(849-50 ; 574-75)$, he hardly touches the pent-up emotion of Euripides' and Erasmus's warrior, who expostulates:

My very blood were murder-tainted,

If this maid, suffering wrongs intolerable,

For my sake and my marriage be destroyed,

With outrage past belief unmerited. (940-43)

Verum nec ipse vacavero piaculo

Si virgo per me perieret, nec non meas

Per nuptias, nova nec serenda sustinens,

Violata miris simil \& indignis modis. (1172 A-B)

As Lumley's Iphigeneia approaches sacrifice, she generates her own apotheosis in ways sufficiently different from the Greek and Latin texts. Using mainly subjunctive rather than indicative moods, Lumley's heroine also emphasizes form, law and authority. To her mother she cautions:

You ought rather to haue thanked Achilles, bicause

he so gentelly hathe promised you his helpe, which maye

happen to bring him into a grete mischefe. I wolde counsell

you therfore to suffer this troble paciently, for I muste

nedes die, and will suffer it willingelye. Consider I praie

you mother, for what a lawfull cause I shalbe slaine.

(1166-74; 797-802)

Her explanatory, appeasing tone is unlike the steeliness of Euripides' figure,

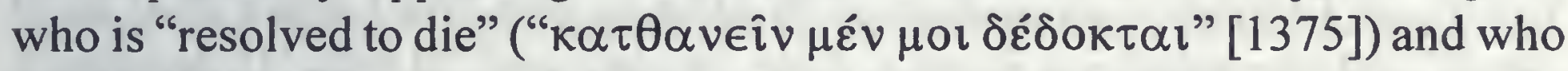
exhorts her mother to mark how well she says so: " $\sigma \kappa \varepsilon \dot{\psi} \psi \alpha \imath$. ., $\mu \hat{\eta} \tau \epsilon \rho, \dot{\omega} \varsigma$ $\kappa \alpha \lambda \omega \varsigma\rangle \varepsilon^{\varepsilon} \gamma \omega$ " (1377). Euripides' Iphigeneia proclaims that one man is "worthier than ten thousand women" (1394) and that a woman shall not "thwart the will divine" (1396). While Lumley may have been misled by Erasmus's "many thousands" ("quam multa sane foeminarum millia" [1181 D]) in miscalculating "one noble man [to be] better than a thousand women" (1197-98; 816), or may simply have "thought the comparison excessive,"38 her Iphigeneia not only insists on the reasoning behind the divine dictate but also resolutely tries to annul any male (as opposed to female) contravention: "seinge my deathe is determined amongste the goddes, trulie no mortall man oughte to witstande it" (1199-1201; 817-18). Purkiss may be severe in suggesting that Lumley is "more misogynistic than Euripides," 39 but clearly Lumley's Iphigeneia sees her death as patient suffering for a lawful cause. Futhermore, an ambivalence about the value or disposability of a woman's life is at the heart of this tragedy, in which the liberty of the heroine to offer 
her life and thereby be the only one to win the day subverts commonplaces about a woman's negligible worth.

The most noticeable attenuations in Lumley's text concern the sacrifice itself. Here, more than at any other moment in the drama, the difficulties of expressing the extraordinary concepts of human acceptance of and witness to death ("martyr" literally means "witness") appear to be pressing heavily on the adolescent translator. Her strategy in staging the climax is to have recourse to plain, unadorned facts, to rein in any tendency to histrionics in this most grisly, tragic, inevitable yet incredible event. Her Iphigeneia is determined to "suffer ... paciently all this troble" $(1211 ; 824-25)$, a resolve that positions her very differently from the "noble" (" $\gamma \in v \nu \alpha i \omega \varsigma$ " [1402]) role played by Euripides' heroine. With a resignation emphasizing compliance more than protest, and with a literalness devoid of poetry, her Iphigeneia bids farewell: "I shalbe compelled by and by to forsake you all and to chaunge my life" (1316-18; 906-7). Lumley may have deduced the idea of compulsion from Erasmus's depiction of being soon forced into eternity, of living in another world:

Alterum mox alterum

Exigemus aevum,

Orbem alterum incolemus. (1184 A)

Her Iphigeneia's leave-taking is without the evanescence, mystery and beauty of Euripides' evocation of "a strange new life [where she] must

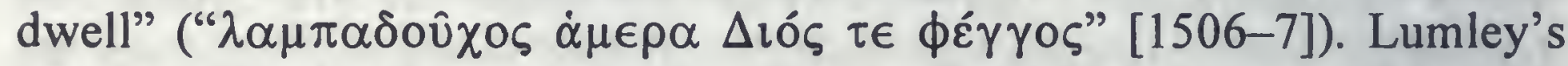
details of the death are minimal, excluding Euripides' mention of the seer laying down "a keen knife which his hand had drawn/Out of its sheath" (1566-67) and of the priest scanning "her throat for fittest place to strike" (1579). Lumley presents the miracle of Iphigeneia's disappearance, the crowd's echoing cry and the sighting of the gasping hind, described by Euripides as "most huge to see and fair to view" (1588), in factual reportage:

And whan all they meruelinge at it, began to giue a greate skritche, then ther appeared unto them a white harte lienge before the aultor, strudgelinge for life. (1368-71; 940-43)

Euripides' substitution of a wild animal, a hart or mountain hind, for the customarily sacrificed domestic animal is a doubly ironic gesture. Not only is the substitute itself a substitute (wild instead of domestic), but it also reverses the sacrificial economy. As Nicole Loraux observes, "untamed nature has irresistibly made its way into the heart of the sacrifice." 40 
Lumley does make two adjustments to her originals in translating this sequence. On hearing Iphigeneia's last words of self-sacrifice for the sake of national glory, the crowd, in Lumley's version, "weare wonderfullye astonied at the stoutenes of her minde" (1354-55; 932). Euripides' crowd

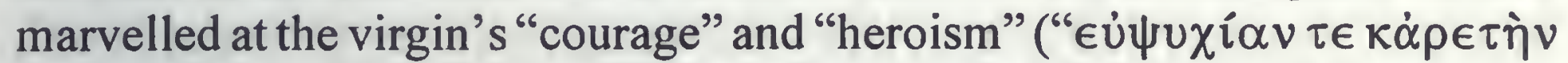
$\tau \hat{\eta} \varsigma \pi \alpha \rho \theta \varepsilon \dot{\varepsilon} \cup u^{\prime \prime}$ [1562]), and Erasmus's crowd at her lofty soul ("virginalis animi celsitudinem" [1185 A]), but Lumley draws special attention to the fullness and tenacity of her heroine's intellect. Lumley's Agamemnon is certain his daughter "is placed in heuen" $(1401 ; 964)$; this conviction, though indebted more to Erasmus's Christian assurance that Iphigeneia is waiting for God to bring about her companionship with heaven-dwellers ("certum est, coelitum/Illam in Deum manere contubernio" [1186 D]) than to Euripides" pagan concept of her "fellowship with Gods" ("غ่v $\theta \in o i \varsigma$ o $\mu \iota \lambda i \alpha \nu$ " [1622]), distils with declarative simplicity the apotheosis of the virgin-martyr. Provisionally, but without obscuring the fact that victory has depended on violence, this Christian conclusion places the perplexity of a daughter's destruction in an eschatological context.

What claim to our attention has this early modern translation of a Greek tragedy by a virtually unknown adolescent? ${ }^{41}$ I would suggest at least two. First, the daring of the enterprise deserves note, but not as the prelude to a series of condescending derogations. Here is a young woman attempting an amazingly stout-minded feat. Does the fact that the play was a gift for her father, who had furnished the means for her education, alter the accomplishment? Does this disclosure locate the translation within the realm of a "degraded activity" which "deprived [women] of any original voice,"42 or confirm that subjectivity entails "subscription to the society that only puts the instrument of rule - the pen - into the hand of citizens it has already ruled"? ${ }^{43}$ As a reflection of the opportunism, the debates about authority and the overlapping public and private spheres of mid-Tudor aristocratic life, is Iphigeneia effectively neutralized? Is Lady Lumley writing against the grain of or in full compliance with her upbringing? Some of these questions, more inflected by the late twentieth century than the mid-sixteenth, are impossible to answer with surety, but it is important that her work prompts them. She is her father's daughter, but not necessarily his creature. She enjoys the privileges, but is not unaware of the perils of noble rank. In Lady Lumley's Tudor translation of a fifth-century BCE tragedy, the allusions to her time are suitably, adroitly oblique. She positions Agamemnon, the strategist king, in enough shadow to caution against uncritical encomium or clear parallels with her own family. 
That the play-text was not intended for performance and that the translation relies more on Erasmus's Latin than Euripides' Greek are not arguments for Lumley's faulty or dishonest commitment. Though a singular and rarely heard voice, she was part of a scholarly tradition. As Marta Straznicky reminds us, "roughly 150 closet plays were written between 1500 and 1660"; the genre, Straznicky contends, has been "virtually reinvented with the recent surge in work on early modern women writers," broadening to include "the literary traditions in which these women wrote" and "the political importance of this purportedly cloistered genre." 44 As for Lumley's use of Erasmus as an aid, she was hardly resorting to a crib or underhandedly plagiarizing the Dutch humanist's work; moreover, her translations of Isocrates from Greek to Latin, possibly undertaken alongside Erasmian translations, ${ }^{45}$ tend to confirm Lumley's interest in the moral issues of government and authority.

The play's second claim to our attention is in heightening our awareness of the role of paraphrastic translation as an early example of a hybrid genre. Here is Euripides filtered through the eyes of a widely read, capable, protected early modern young woman, whose domestic idiom, distinctive word choices, misconstruals, deliberate exclusions and sometimes softened, sometimes heightened tragic details convey the blended experience of the Greek and Latin texts. We can only conjecture whether Lady Lumley felt allied with or totally removed from Iphigeneia. Did the abnormality of the play's events provide her with a catharsis similar to the one undergone by the ancient Athenian audience? The concept of blendedness applies not just to the combination of ancient and Tudor texts but to the linkages between early modern and postmodern sensibilities. How do we respond to or appropriate Lady Lumley's work? I have sketched some possibilities. Without building an estimate of her on "restrictive categories and competitive hierarchies," 46 it is both feasible and illuminating to attend to this translation as the product of a unique intelligence and distillation of circumstances. Such attention encourages us to view translation as a reading or rewriting of a text that creates its own originality; it concentrates less on so-called fidelity - which, as Walter Benjamin (in the tradition of Pound) has remarked, "impedes the rendering of the sense" - but allows the reader to perceive how "a translation touches the original lightly and only at the infinitely small point of the sense, thereupon pursuing its own course according to the laws of fidelity in the freedom of linguistic flux." 47 


\section{Notes}

1. Sometimes called Isocrates" "Cyprian" orations, the orations Lady Lumley translates are addressed to noteworthy inhabitants of Cyprus - one to Demonicus, a young man whose father had recently died, on the topic of practical ethics, and two to Nicocles, the young king, on a ruler's conduct toward his people and on the duties of subjects. The fourth is an epideictic oration eulogizing Nicocles' father, Evagoras. See Isocrates, trans. G. Norlin, 3 vols. (London: William Heinemann Ltd., 1928), vols. I and III.

2. Henry Fitzalan, born in 1513, embodied the sense of action in his motto, "virtutis laus actio"; diplomat, administrator, strategist and man of letters, he was "of due \& comely proportion, strong of bone, ... void of fogginess or fatness" (BL MS Royal 17. A. ix. 36). He served as Deputy-General of Calais for four years (following which he was created Earl of Arundel), commander at the siege of Boulogne and Lord Steward of the Household for ten years stretching through the reigns of Mary and Elizabeth. A Catholic, he supported Northumberland's plans for the coronation of Lady Jane Grey and then, when the tide turned, adroitly positioned himself in Queen Mary's Council. Elizabeth appointed him Chancellor of the University of Oxford in 1559, but after a few months he resigned; however, she rebuffed this widower as a suitor. He was sent to prison twice - to the Tower because of his support of the re-marriage of his son-in-law, the Duke of Norfolk, to Mary, Queen of Scots, and to the Marshalsea for his suspected involvement in the Ridolfi plot. Having survived all his children and his two wives, Arundel died in London in 1580. See James E. Doyle, The Official Baronage of England, 3 vols. (London: Longmans, Green \& Co., 1886), I: 81-83; Neville Williams, Thomas Howard Fourth Duke of Norfolk (London: Barrie and Rockliff, 1964).

3. Harold H. Child, ed., Iphigenia at Aulis Translated by Lady Lumley (London: Malone Society, 1909), p. vi. All citations from Lumley's play will include references to both this edition and that of Diane Purkiss in Three Tragedies by Renaissance Women, Penguin Renaissance Dramatists (Harmondsworth, Middlesex: Penguin Books, 1998).

4. Purkiss, p. xxiv. See The Lumley Library: The Catalogue of 1609, ed. Sears Jayne and Francis Johnson (London: Trustees of the British Museum, 1956), nos. 1591a and 1736a, pp. 191, 205. 1591a is an edition (Cologne, 1519) of Erasmus's translation of Euripides' Hecuba and Iphigeneia. 1736a (Louvain, 1520), an edition of both plays in Greek, contains the "Lumley" signature below that of Thomas Cranmer ("Thomas Cantuarium") on the title page. The marginal notes in Hecuba and Iphigeneia are in different hands; those in Hecuba are mainly in Greek, while those in Iphigeneia add explanatory words in Greek and Latin marginally and interlinearly, cite Erasmus's translation as a kind of aide-mémoire in the margins and represent the work of someone attempting to translate the Greek. A comparison of this hand and that of Lady Lumley indicates significant differences in letter formation; hence, despite the intriguing possibility, these notations are likely not Lady Lumley's.

5. Purkiss, pp. xxiv-xxv.

6. Ibid., p. xxxviii.

7. George Ballard, Memoirs of Several Ladies of Great Britain Who Have Been Celebrated for Their Writings or Skill in the Learned Languages, Arts and Sciences (Oxford: W. Jackson, 1752), p. 180. Ballard is citing Erasmus, Ep. 31, Lib. 19: "scena rerum humanarum invertitur ... Foeminae libris indulgent." 
8. Nicholas Udall, "To the most vertuous Ladie and most gracious Quene Katherine ... ," Preface to the Paraphrase of Erasmus upon the gospell of sainct John. The First Tome or Volume of the Paraphrase of Erasmus upon the Newe Testament (London: Edward Whitchurche, 1548), fol. cccxcix. Queen Katherine Parr commissioned Udall as the general editor of this translation, a project which her step-daughter, Mary Tudor, had undertaken until ill health forced her to stop.

9. Among the young Elizabeth's lost works are a translation into Latin of a play by Euripides and a translation of two orations of Isocrates; see Horace Walpole, A Catalogue of the Royal and Noble Authors of England, 2 vols. (London: R. and J. Dodsley, 1759), I: 31.

10. Elaine Beilin, Redeeming Eve: Women Writers of the English Renaissance (Princeton: Princeton University Press, 1987), p. 156.

11. Barry Weller and Margaret Ferguson, eds., The Tragedy of Mariam, the Fair Queen of Jewry (Berkeley: University of California Press, 1994), pp. 26, 27.

12. Beilin, p. 157.

13. Euripidis Iphigenia in Aulide, e Graeco Sermone in Latinum Traducta, Desiderio Erasmo Roterdamo Interprete, Opera Omnia in Decem Tomos Distincta (Leiden: Petri Vander, 1703; rpt. London: Gregg Press, 1962), I: 1155-86. All quotations from Erasmus's Iphigenia will be based on this text.

14. David H. Greene, "Lady Lumley and Greek Tragedy," The Classical Journal, 36 (1941), p. 547.

15. Frank D. Crane, "Euripides, Erasmus, and Lady Lumley," The Classical Journal, 39 (1944), p. 227.

16. Ibid., p. 228.

17. Two entries in the Lumley Catalogue concern this manuscript juvenilia: no. 1743 ("Exercises in Greek and Latin of Lorde Maltravers and ladie Lumley, done when thei were yoonge, of their owne hand wrytinge") and no. 1753 ("Exercises and translations out of Greeke into latin and otherwise of Marie Duchesse of Suffolke, Jane ladie Lumley, and Sir John Ratclif when they were yonge, of their owne hande wrytinge, bound up together"); see Jayne and Johnson, pp. 206, 207.

18. Ibid., p. 4.

19. Ibid., p. 5.

20. Purkiss, p. xv.

21. Domestic information about Lady Lumley is scarce. Her three children, Charles, Thomas and Mary, died in infancy. Her presence was noted at public events: at Mary's coronation and at the funeral of her sister, the Duchess of Norfolk; see Williams, p. 34. Lady Lumley was the recipient of an exquisitely illuminated vellum manuscript of Latin sayings collected by Sir Nicholas Bacon for his own gallery at Gorhambury and presented as a token of his high regard for the mistress of Nonsuch mansion. In the chancel of the church at Cheam in Surrey, her black marble burial monument of the "late medieval type" depicts an aristocrat at prayer, with two male children and a female child close by, above an inscription commemorating her piety, moral virtues and true nobility: "Praestans Pietatis studio, virtutum officiis, et vera nobilitatis gloria"; see Judith W. Hurtig, "Death in Childbirth: Seven- 
teenth-Century English Tombs and Their Place in Contemporary Thought," Art Bulletin, 65 (1983), p. 610, and Ballard, p. 122.

22. Mary Thomas Crane, Framing Authority: Sayings, Self, and Society in Sixteenth-Century England (Princeton: Princeton University Press, 1993), p. 91.

23. Purkiss, p. 168.

24. Mary Thomas Crane, p. 90.

25. Jayne and Johnson, p. 7. For further information on Lord Lumley and Spenser's possible acquaintance with Lumley's collection at Tower Hill, see W. H. Welply, "Literary and Historical Notes: John, Baron Lumley, 1534?-1609," Notes and Queries, 141 (1941), pp. 86-88.

26. Elizabeth McCutcheon, ed. and trans., Sir Nicholas Bacon's Great House Sententiae, English Literary Renaissance Supplements 3 (Claremont, CA: University of Hawaii and Sir Francis Bacon Foundation and Library, 1977), p. 5.

27. Pearl Hogrefe, Tudor Women: Commoners and Queens (Ames: Iowa State University Press, 1975), p. 106.

28. C. A. E. Luschnig, Tragic Aporia: A Study of Euripides' Iphigenia at Aulis (Berwick, Victoria, Australia: Aureal Publications, 1988), p. 5.

29. Nicole Loraux, Tragic Ways of Killing a Woman, trans. A. Foster (Cambridge, MA: Harvard University Press, 1987), p. 43.

30. Frank D. Crane, p. 224.

31. Euripides, with an English translation by A. S. Way, 4 vols. (Cambridge, MA: Harvard University Press, 1912), vol. 1. Quotations from Iphigeneia at Aulis will be based on this text, with references to Way's translation incorporated parenthetically.

32. On the strict estimate of line length (an easier task for Euripides' verse than for Lumley's prose, especially given the different font types), the Malone text is roughly $87 \%$ of the Greek, and the Penguin text is 61\%; an average of these two percentages yields the calculation — based solely on number of lines - that Lumley's play is three-quarters the length of Euripides'.

33. Udall, "To the Ientel Christian reader," op. cit., sig. A.i.

34. Frank D. Crane, p. 227. However, Crane wastes no time with this possible "excuse" for Lumley's mistake, but hammers home the conclusion that "her version succeeds only in reducing high tragedy to a mediocre tale of "troble"' (p. 228).

35. Before the addition of Cranmer's books, the Lumley Library contained many Bibles - in Latin (Antwerp, 1526; Paris, 1532; Paris, 1540; Venice, 1544; Paris, 1545), Greek (Strasbourg, 1526; Basel, 1545), Hebrew (Venice, 1525-28), and French (Louvain, 1550), as well as a polyglot version (Basel, 1549) and one with the Latin commentary of the Venerable Bede (Basel, 1533); see Jayne and Johnson, pp. 48-53.

36. F. F. Bruce quotes More's A Dialogue Concerning Heresies, The English Bible: A History of Translations (London: Lutterworth Press, 1961), p. 22.

37. MS. Bodley 959. Genesis-Baruch in the Earlier Version of the Wycliffite Bible, ed. Conrad Lindberg, 5 vols. (Stockholm: Almqvist \& Wiksell, 1965), IV: 306; Biblia Sacra Iuxta 
42 / Renaissance and Reformation / Renaissance et Réforme

Vulgatam Versionem, recensuit Robertus Weber, 2 vols. (Stuttgart: Württembergische Bibelanstalt, 1969).

38. Beilin, p. 314.

39. Purkiss, p. 173.

40. Loraux, p. 35.

41. This designation itself is admittedly anachronistic; see Sara Mendelson and Patricia Crawford, Women in Early Modern England(Oxford: Clarendon Press, 1998), pp. 78-79.

42. M. E. Lamb, "The Cooke Sisters: Attitudes toward Learned Women in the Renaissance," Silent but for the Word: Tudor Women as Patrons, Translators, and Writers of Religious Works, ed. M. Hannay (Kent, OH: Kent State University Press, 1985), pp. 116, 125.

43. Jonathan Goldberg, “Hamlet's Hand," Shakespeare Quarterly, 39 (1988), p. 311.

44. Marta Straznicky, "Recent Studies in Closet Drama," Studies in the English Renaissance, 28 (1998), pp. 142, 159.

45. The Lumley library contained six separate editions of Isocrates in both Latin and Greek (numbers 1889, 1894, 1952, 1991, 2068, 2082 in the catalogue) before the acquisition of Cranmer's two texts of Erasmian translations (numbers 1189, 1740). See Jayne and Johnson, pp. 219, 220, 225, 228, 236, 237, 150, 206.

46. Margaret J. M. Ezell, Writing Women's Literary History (Baltimore: Johns Hopkins University Press, 1993), p. 165.

47. Walter Benjamin, "The Task of the Translator," Illuminations, ed. Hannah Arendt, trans. Harry Zohn (New York: Schocken Books, 1969), pp. 78, 80. 